\title{
Pengaruh Status Sosial Ekonomi dan Pendidikan Terhadap Kesadaran Kepemilikan Sertifikat Tanah Kabupaten Luwu Timur
}

\author{
Andi Muhammad Hasbi Munarka ${ }^{1}$ \\ Reynal Rustam ${ }^{2}$ \\ No. HP $08124200669^{1}$ \\ ${ }^{\mathbf{1}}$ Alamat Korespondensi: J1 Anggrek No. 16 Palopo \\ Email:
}

\begin{abstract}
Abstrak
Tujuan penelitian ini untuk menganalisis dan pengetahuan pengaruh dari pengaruh Status Sosial Ekonomi dan Pendidikan Terhadap Kesadaran Kepemilikan Sertifikat Tanah di Kabupaten Luwu Timur dengan sampel 100 responden, yang diambil secara purposive deskriptif. Selanjutnya teknik pengumpulan data adalah metode penyebaran angket atau kuesioner dengan menggunakan skala likert, yang dianalisis dengan analisis regresi berganda .

$Y=3,503+0,833 X_{1}-0,111 X_{2}$. Interpretasi dari regresi di atas adalah sebagai berikut :Konstanta (a) Ini berarti semua variabel bebas memiliki nilai nol (0) maka nilai variabel terikat sebesar 3,503. Status sosial ekonomi $\left(X_{1}\right)$ terhadap beta $(Y)$ Nilai koefisien status sosial ekonomi untuk variabel $X_{1}$ sebesar 0,833. Hal ini mengandung arti bahwa setiap kenaikan bukti fisik satu satuan maka variabel beta (Y) akan naik sebesar 0,833 dengan asumsi bahwa variabel bebas yang lain dari model regresi adalah tetap. pendidikan $\left(X_{2}\right)$ terhadap beta $(Y)$. Nilai koefisien pendidikan untuk variabel $X_{2}$ sebesar-0,111. Hal ini mengandung arti bahwa setiap kenaikan keandalan satu satuan maka variabel beta $(Y)$ akan turun sebesar 0,111 dengan asumsi bahwa variabel bebas yang lain dari model regresi adalah tetap.
\end{abstract}

Kata Kunci: Status social ekonomi, pendidika, kepemilikan sertifikasi tanah.

\section{Pendahuluan}

Kebijakan Pemerintahan dalam keagarariaan di Indonesia sepertinya selalu terjadi persoalan pelik dimana terjadi kontradiksi kepntingan umum dan rakyat kecil yang tidak tercipta sinergis diantara dua kepentingan namun terdapat juga prestasi yang pantas dibanggakan. BPN ketika masih bernama Direktorat Jenderal
Agraria dalam Depertemen Dalam Negeri sejak tahun 1981 (melalui SK Mendagri No. 189 dan 220 Tahun 1981 meluncurkan suatu proyek administrasi/pensertifikatan secara massal bernama Proyek Operasi Nasional Agrari (Prona). Memang tingkat keberhasilannya masih terlalu rendah. Dalam masa empat tahun pertama yang (1981-1985) misalnya, Prona yang mentargetkan 795.000 sertifikat pertahun ternyata realisasinya hanya mencapai rata-rata 250.000 sertifikat pertahun atau sekitar 30\% atau bahkan hanya setara 1,5 kali prestasi pendaftaran tanah konvensional/sporadic pada masa itu yakni 168.000 sertifikat pertahun. Bandingkan misalnya dengan kinerja Proyek Ajudikasi sejak dimulainya yaitu tahun 1994 hingga menjelang akhir tahun 2000. Proyek ini berhasil melampaui terget untuk kurun waktu tersebut dan prestasi produktivitasnya mencapai lima hingga enam kali lipat pendaftaran tanah konvensional/sporadic.

Prestasi kelembagaan pendaftaran tanah lainnya yang pantas kita catat terletak pada tataran kebijakan menjelang akhir abad 20, yaitu diakomodasikannya kehendak masyarakat pemilik tanah untuk lebih memperoleh kepastian dalam perlindungan hukum dengan telah diperolehnya 
sertifikat tanah oleh pemegang hak. Prestasi tersebut ditandai dengan diterbitkannya Peraturan Pemerintah RI No. 24 Tahun 1997 dan UU N0. 20 tahun 2009 tentang Pendaftaran Tanah.

Isi peraturan pokok pendaftaran tanah yang baru itu hemat penulis memang jauh lebih baik daripada Peraturan Pemerintah RI No. 10 Tahun 1961 dan Peraturan Pemerintah RI No. 24 Tahun 1997 sebelumnya yang digantikannya. Disempurnakan kembali peraturan tersebut UU N0. 20 tahun 2000 dan KEPRES N0. 34 tahu 2003 dengan KEPRES N0. 34 tahun 2003 dibarengi PERPRES N0. 10 tahun 2006, mengatur pelaksanaan dilapangan bagi penanganan Pertanahan oleh Badan Pertanahan Nasional.

Kini pemilik sertifikat tanah sebagai pemegang hak milik atas tanah tidak dapat diganggu gugat oleh siapapun setelah sertifikat tersebut "berusia" lima tahun. Hanya pada usia sertifikat dibawah lima tahun (balita) sejalan pihak lain diberikan kesempatan untuk menggugat kepemilikan atau penguasaan hak atas tanah si pemegang sertifikat bilamana memang mempunyai bukti yang juga berkekuatan hukum sama derajatnya. Penegasan tersebut bilamana kita baca dari bunyi Pasal 32 Peraturan Pemerintah No. 24 Tahun 1997:

(1) Sertifikat merupakan tanda bukti hak yang berlaku sebagai alat pembuktian yang kuat mengenai data fisik dan data yuridis yang termuat didalamnya sepanjang data fisik dan data yuridis tersebut sesuai dengan data yang ada dalam surat ukur dan buku tanah hak yang bersangkutan.

(2) Dalam hal atas suatu bidang tanah sudah diterbitkan sertifikat secara sah atas nama orang atau badan hokum yang memperoleh tanah tersebut dengan etikad baik dan secara nayata menguasainya, maka pihak lain yang merasa mempunyai hak atas tanah itu tidak dapat lagi menuntut pelaksanaan hak tersebut apabila dalam waktu 5 (lima) tahun sejak diterbitkannya sertifikat itu tidak mengajukan keberatan secara tertulis kepada pemegang sertifikat dan kepala Kantor Pertanahan yang bersangkutan ataupun tidak mengajukan gugatan ke Pengadilan mengenai penguasaan tanah atau penertbitan sertifikat tersebut.

Jadi jelasnya sekali bidang tanah milik kita sudah disertifikatkan maka, tidak mudah bagi orang lain atau pihak manapun untuk merebutnya dari tangan kita, bahkan bunyi Putusan MA tanggal 3 Nopember 1971 Nomor 383/K/Sip/1971 adalah Pengadilan tidak berwenang membatalkan sertifikat. Hal tersebut termasuk kewenangan Administrasi.

Tanah ditempatkan sebagai suatu bagian penting bagi kehidupan manusia. Seiring dengan berkembangnya jumlah penduduk, kebutuhan akan tanah terus meningkat. Kebutuhan-kebutuhan tersebut kadang-kadang menimbulkan perselisihan kepentingan sehingga masalah pertahanan menjadi hal yang sering dihadapi oleh masyarakat.

Di Negara Indonesia pada saat ini sudah semakin maju peraturanperaturan yang mengatur tentang pertanahan, tetapi pada kenyataannya masih ditemui masyarakat pedesaan atau bisa dikatakan masyarakat adat yang belum mengerti dengan peraturan-peraturan mengenai tanah yang berlaku di Negara Republik Indonesia.

Bahkan ironisnya hal itu juga terjadi di Ibukota Negara Indonesia, Jakarta.Ini 
menunjukkan bukti bahwa proses landreform yang masih jauh dari apa yang diharapkan. Menurut data yang ada, tanah yang sudah terdaftar di Indonesia $\pm 30 \%$ saja atau sekitar 30 juta bidang tanah. Minimnya bukti kepemilikan atas tanah ini menjadi salah satu penyebab minimnya proses pendaftaran hak atas tanah.

Hal lain yang menjadi penyebab adalah minimnya pula pengetahuan masyarakat akan arti pentingnya bukti kepemilikan hak atas tanah. Proses pembuatan sertipikat itu mereka harus memiliki surat-surat kelengkapan untuk tanah yang mereka miliki.

Tanah yang dimiliki masyarakat pedesaan atau masyarakat adat itu dimiliki secara turun temurun dari nenek moyang mereka, surat kepemilikan tanah yang mereka miliki sangat minim sekali bahkan ada yang tidak memiliki sama sekali. Mereka menempati dan menggarap tanah tersebut sudah berpuluh-puluh tahun sehingga masyarakatpun mengetahui bahwa tanah tersebut.

Salah satu kebutuhan primer dari manusia adalah memiliki rumah yang tentunya didirikan di atas sebidang tanah. Dalam pandangan masyarakat, dengan memiliki rumah, seseorang dianggap telah mapan secara finansial sehingga tidak mengherankan jika setiap orang akan berupaya semaksimal mungkin memperoleh rumah dan tanah.

Hak atas tanah merupakan hak yang melekat yang tidak dapat dihilangkan begitu saja. Hak atas tanah, salah satunya diperoleh setelah melakukan suatu transaksi, misalnya jual beli. Meskipun telah dilakukan suatu transaksi jual beli, tidak secara otomatis hak atas tanah beralih kepada pembeli, karena terlebih dahulu harus melalui tahapan tahapan tertentu agar kepemilikan tanah dapat beralih dari pihak yang satu ke pihak yang lainnya.

Merupakan suatu kebutuhan bagi masyarakat di indonesia selaku pemegang hak atas tanah untuk memperoleh kepastian dan perlindungan hukum atas haknya. Selain itu, adanya kepentingan masyarakat dan pemerintah untuk memperoleh informasi atas tanah, yang diperlukan dalam mengadakan perbuatan hukum mengenai bidang-bidang tanah dan rumah susun yang sudah terdaftar, diperlukan adanya Hukum Tanah Indonesia yang salah satu ketentuannya mengatur mengenai pendaftaran tanah demi terselenggaranya tertib hukum adminidtrasi pertahanan.

Tanah yang sudah didaftarkan harus memiliki bukti-bukti autentik yang tentunya dalam bentuk tertulis. Bukti autentik tersebut dibuat dalam bentuk sertifikat atas tanah. Dengan dibuktikannya sertifikat tanah, secara yuridis, negara mengakui kepemilikan atas suatu tanah terhadap mereka yang namanya terdaftar dalam sertifikat tanah tersebut. Dengan demikian, pihak lain tidak dapat mengganggu-gugat kepemilikan atas tenah tersebut.

\section{Metode Penelitian}

Penelitian ini akan dilaksanakan pada kantor pertanahan daerah Kabupaten Luwu Timur. Sumber data yang digunakan yaitu data primer yang diperoleh melalui hasil penelitian secara langsung terhadap obyek yang diteliti yaitu masyarakat di puncak indah kecamatan malili. Data sekunder yaitu data yang diperoleh dari 
berbagai sumber dokumen-dokumen atau laporan tertulis lainnya yang ada di kantor pertanahan daerah.

Jenis data yang digunakan yaitu Data Kuantitatif, data yang dapat dihitung berupa angka-angka. Data Kualitatif, data yang tidak dapat dihitung atau data yang berbentuk informasi, yang diperoleh dari hasil wawancara dengan pegawai pertanahan daerah dan masyarakat puncak Indah Kecamatan Malili.

Populasi dalam penelitian ini adalah seluruh masyarakat desa puncak indah yang terdiri dari 1000 responden yang berdomisili di Puncak Indah Mengingat secara teknis peneliti tidak dapat meneliti setiap anggota individu yang terdapat di desa puncak indah Kecamatan Malili. Mengingat pula akan keterbatasan waktu, tenaga, dan biaya, maka peneliti mengambil dari beberapa bagian dari populasi yang disebut sampel. Sampel menunjukkan jumlah responden yang mewakili populasi. Dalam penelitian ini jumlah sampel yang diteliti sebanyak 100 responden. Dengan menggunakan rumus slovin.

Untuk mengumpulkan data dalam penelitian ini maka digunakan metode penelitian lapangan yaitu wawancara yaitu melakukan wawancara Iangsung terhadap responden yang dalam hal ini adalah masyarakat, hal ini dimaksudkan melalui percakapan dua arah atas inisiatif pewawancara demi memperoleh informasi dari responden. Dokumentasi yaitu mendapatkan data tertulis yang dibutuhkan, yang berasal dari dokumen dan catatan-catatan kantor Pertanahan seperti : jumlah KK, banyaknya pendaftaran sertifikat tanah, serta data lainnya yang dibutuhkan dalam penelitian ini. Kuesioner (angket) yaitu pengumpulan data melalui daftar pertanyaan yang disiapkan masing-masing responden. Serta Penelitian Kepustakaan, yaitu penelitian yang bertujuan untuk memperoleh konsep dan landasan teori dengan mempelajari berbagai literature, buku, dan dokumen yang berkaitan dengan objek pembahasan.

Metode analisis data yang digunakan terdiri dari Analisis deskriptif yaitu suatu analisis untuk yang menguraikan pendidikan dan status sosial terhadap kepemilikan akta tanah. Analisis regresi linear berganda yakni suatu analisis untuk melihat sejauh mana pengaruh pemilikan akta tanah terhadap pendidikan dan status sosial ekonomi di desa puncak indah kecamatan malili kabupaten luwu timur.

\section{Hasil dan Pembahasan}

\section{Deskriftif Responden}

\section{Deskripisi Responden Berdasarkan Jenis Kelamin}

Dari hasil penyebaran kuesioner maka didapat jumlah responden pria dan wanita sebagai berikut :

pengelompokkan responden berdasarkan umur berikut ini :

Tabel 1: Umur Responden

\begin{tabular}{|l|l|c|c|}
\hline No & $\begin{array}{l}\text { Kategori } \\
\text { Jenis } \\
\text { Kelamin }\end{array}$ & Jumlah & Persentase \\
\hline 1 & Pria & 78 & $78 \%$ \\
\hline 2 & Wanita & 22 & $22 \%$ \\
\hline \multicolumn{2}{|c|}{ Jumlah } & 100 & $100 \%$ \\
\hline
\end{tabular}

Umur responden dapat dikelompokkan seperti pada tabel 1 dan dari hasil 
pengelompokkan terlihat kelompok terbesar responden adalah yang berumur 31 sampai 40 tahun sebanyak 42 orang sedangkan kelompok terkecil berasal dari umur di atas 50 tahun sebanyak 10. Umur bisa menentukan tingkat kedewasaan seseorang sehingga hal ini bisa mempengaruhi dalam perilakunya dan cara pemikirannya dalam kesadaran untuk memeliki sertifikat tanah.

\section{Deskripsi Responden Berdasarkan Pendidikan Terakhir}

Pendidikan terakhir yang ditempuh oleh responden dapat dikelompokkan sebagai berikut :

\section{Tabel 2: Pendidikan Responden}

\begin{tabular}{|c|l|c|c|}
\hline No & $\begin{array}{c}\text { Kategori } \\
\text { Pendidikan }\end{array}$ & Jumlah & Persentase \\
\hline 1 & SD & 10 & $10 \%$ \\
\hline 2 & SLTP & 20 & $20 \%$ \\
\hline 3 & SLTA & 50 & $50 \%$ \\
\hline 4 & D3 & 7 & $7 \%$ \\
\hline 5 & S 1 & 20 & $20 \%$ \\
\hline 6 & S 2 & 3 & $3 \%$ \\
\hline \multicolumn{2}{|c|}{ Jumlah } & 100 & $100 \%$ \\
\hline
\end{tabular}

Latar belakang pendidikan responden adalah dari SD sampai Sarjana, dengan jumlah responden yang berpendidikan Starata 1 sebanyak 20 responden, SLTA $50 \%$, sementara yang berpendidikan S2 hanya 3 responden. Tingkat pendidikan yang ditempuh seseorang menunjukkan tingkat pengetahuan dan wawasan yang dimiliki, yang akan berpengaruh pada kemampuan terhadap suatu permasalahan seperti seperti kesadaran mereka akan kepemilikan sertifikat tanah.

\section{Deskripsi Responden Berdasarkan Pekerjaan}

Pengelompokan respon berdasarkan pekerjaan sebagai berikut:

Tabel 3: Pekerjaan Responden

\begin{tabular}{|c|l|c|c|}
\hline No & \multicolumn{1}{|c|}{$\begin{array}{c}\text { Kategori } \\
\text { Pekerjaan }\end{array}$} & Jumlah & Persentase \\
\hline 1 & $\begin{array}{l}\text { Ibu rumah } \\
\text { tangga }\end{array}$ & 30 & $30 \%$ \\
\hline 2 & Wiraswasta & 55 & $55 \%$ \\
\hline 3 & Non PNS & 10 & $10 \%$ \\
\hline 4 & PNS & 5 & $5 \%$ \\
\hline & Jumlah & 100 & $100 \%$ \\
\hline
\end{tabular}

Dari tabel di atas responden memiliki latar belakang pekerjaan yang berbeda-beda, responden yang bekerja sebagai wirausaha sebanyak 55 orang atau sebesar 55\%, sementara responpen yang lebih kecil adalah responden yang bekerja sebagai PNS sebanyak 5 orang atau sebesar $5 \%$.

\section{Analisis Data \\ Uji Validitas}

Uji validitas dilakukan untuk mengetahui tingkat kevalidan indikator yang digunakan sebagai alat ukur variabel. Pengujian validitas menggunakan korelasi bivariat yang dilakukan dengan menghitung korelasi antara skor masingmasing butir pertanyaan dengan total skor variabel, dengan kententuan sig. $\leq 0,05$ berarti valid dan sig. $>0,05$ berarti tidak valid. Berikut ini hasil uji validitas masing-masing indikator. 
Tabel 4: Hasil Uji Validitas

\section{Correlations}

\begin{tabular}{|rl|r|r|r|r|}
\hline & & $\mathrm{x} 1$ & $\mathrm{x} 2$ & $\mathrm{x} 3$ & $\mathrm{x} 1.1$ \\
\hline \multirow{4}{*}{ x1 } & Pearson Correlation & 1 &, $441^{* *}$ &, $540^{* * *}$ &, $821^{* *}$ \\
& Sig. (2-tailed) & &, 000 &, 000 &, 000 \\
& $\mathrm{~N}$ & 100 & 100 & 100 & 100 \\
& Pearson Correlation &, $441^{* *}$ & 1 &, $455^{* *}$ &, $787^{* *}$ \\
$\mathrm{x} 2$ &, 000 & &, 000 &, 000 \\
& Sig. (2-tailed) & 100 & 100 & 100 & 100 \\
& N &, $540^{* *}$ &, $455^{* *}$ & 1 &, $815^{* *}$ \\
& Pearson Correlation &, 000 &, 000 &, 000 \\
x3 & Sig. (2-tailed) &, $821^{* *}$ &, $787^{* *}$ &, $815^{* *}$ & 100 \\
& N &, 000 &, 000 &, 000 & 1 \\
& Pearson Correlation & 100 & 100 & 100 & 100 \\
\hline
\end{tabular}

**. Correlation is significant at the 0.01 level (2-tailed).

Correlations

\begin{tabular}{|rl|r|r|r|r|}
\hline & & $y 1$ & $y 2$ & $y 3$ & \multicolumn{1}{|c|}{$y$} \\
\hline \multirow{4}{*}{ y1 } & Pearson Correlation & 1 &, $537^{* *}$ &, $530^{* *}$ &, $843^{* *}$ \\
& Sig. (2-tailed) & &, 000 &, 000 &, 000 \\
& N & 100 & 100 & 100 & 100 \\
& Pearson Correlation &, $537^{* *}$ & 1 &, $427^{* *}$ &, $799^{* *}$ \\
y2 &, 000 & 100 &, 000 &, 000 \\
& Sig. (2-tailed) &, $530^{* *}$ &, $427^{* *}$ & 100 & 100 \\
& N &, 000 &, 000 & 1 &, $805^{* *}$ \\
& Pearson Correlation & 100 & 100 &, 000 \\
y3 & Sig. (2-tailed) &, $843^{* *}$ &, $799^{* *}$ &, $805^{* *}$ & 100 \\
& N &, 000 &, 000 &, 000 & 1 \\
& Pearson Correlation & 100 & 100 & 100 & 100 \\
\hline
\end{tabular}

**. Correlation is significant at the 0.01 level (2-tailed).

Berdasarkan tabel hasil uji validitas dapat diketahui bahwa semua item pertanyaan/indikator variabel status sosial, pendidikan dan kesadaran kepemilikan sertifikat tanah dinyatakan valid karena dari hasil korelasi antara hasil jawaban responden pada tiap item pertanyaan/indikator dengan skor didapat hasil yang signifikan, yaitu nilai sig. $<0,05$.

\section{Uji Reliabilitas}

Uji reliabilitas digunakan untuk mengetahui apakah instrumen/indikator yang digunakan dapat dipercaya atau handal sebagai alat ukur variabel, apabila nilai cronbach's alpha $(\alpha)$ suatu variabel 3 0,60 maka indikator yang digunakan oleh variabel tersebut reliabel, sedangkan nilai cronbach's alpha $(\alpha)$ suatu variabel $<0,60$ maka indikator yang digunakan 
oleh variabel tersebut tidak reliabel. Hasil uji reliabilitas adalah sebagai berikut.

Tabel 5: Hasil uji Reliabilitas

\begin{tabular}{|l|c|c|}
\hline \multicolumn{1}{|c|}{ Variabel } & $\begin{array}{c}\text { Cronbach's } \\
\text { Alpha }\end{array}$ & Keterangan \\
\hline $\begin{array}{l}\text { Status sosial } \\
\text { ekonomi }\end{array}$ & $0,829>0,60$ & Reliabel \\
\hline Pendidikan & $0,744>0,60$ & Reliabel \\
\hline $\begin{array}{l}\text { Sertifikat } \\
\text { tanah }\end{array}$ & $0,748>0,60$ & Reliabel \\
\hline
\end{tabular}

Sumber: data diolah 2013

Tabel 6: Hasil Regresi Berganda
Hasil uji reliabilitas memperlihatkan nilai cronbach's alpha semua variabel di atas 0,60, sehingga dapat disimpulkan indikator yang digunakan oleh variabel status sosial ekonomi, dan pendidikan dapat dipercaya atau handal untuk digunakan sebagai alat ukur variabel.

\section{Analisis Regresi Berganda}

Pada penelitian ini teknik analisa data yang digunakan adalah regresi berganda. Teknik analisa ini digunakan untuk mengetahui besarnya pengaruh antara status sosial ekonomi dan pendidikan terhadap kesadaran kepemilikan sertifikat tanah di Luwu Timur. Dengan pengolahan SPSS versi 20.0 for windows maka didapat hasil regresi sebagai berikut:

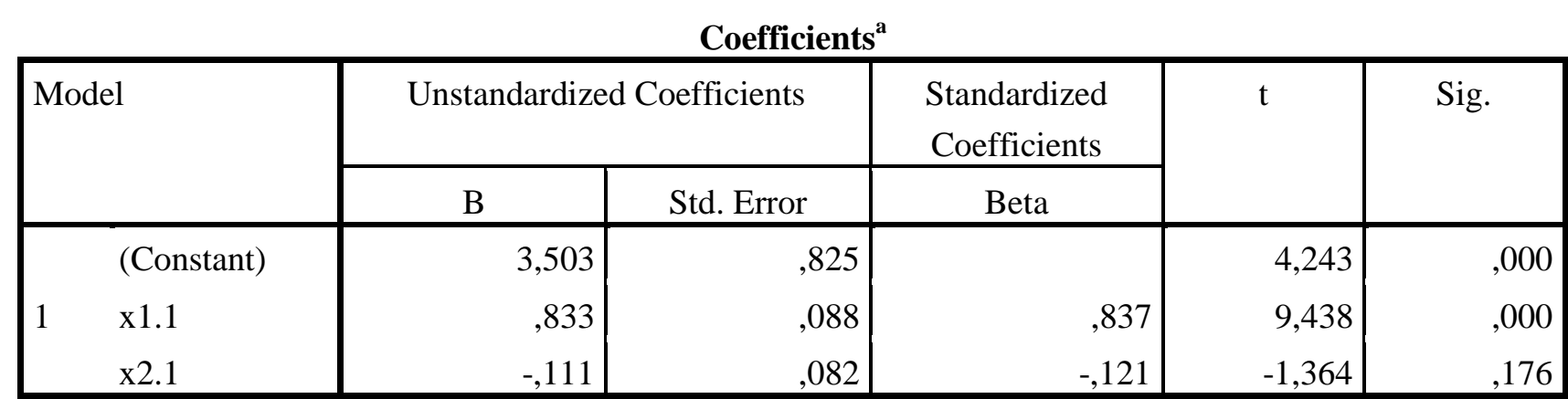

a. Dependent Variable: y

$Y=3,503+0,833 X_{1}-0,111 X_{2}$

Interpretasi dari regresi di atas adalah sebagai berikut :

1. Konstanta (a)

Ini berarti semua variabel bebas memiliki nilai nol (0) maka nilai variabel terikat sebesar 3,503 .

2. Status sosial ekonomi $\left(\mathrm{X}_{1}\right)$ terhadap beta $(\mathrm{Y})$ Nilai koefisien status sosial ekonomi untuk variabel $X_{1}$ sebesar 0,833. Hal ini mengandung arti bahwa setiap kenaikan bukti fisik satu satuan maka variabel beta (Y) akan naik sebesar 0,833 dengan asumsi bahwa variabel bebas yang lain dari model regresi adalah tetap.

3. pendidikan $\left(\mathrm{X}_{2}\right)$ terhadap beta $(\mathrm{Y})$

Nilai koefisien pendidikan untuk variabel $\mathrm{X}_{2}$ sebesar -0,111. Hal ini mengandung arti bahwa setiap kenaikan keandalan satu satuan maka variabel beta (Y) akan turun sebesar 0,111 dengan asumsi bahwa variabel bebas yang lain dari model regresi adalah tetap. 


\section{Pengujian Hipotesis}

Untuk pengujian hipotesis, yang kemudian diuji dengan uji $-\mathrm{t}$ dan uji $-\mathrm{F}$, hipotesis bisa dikemukakan sebagai berikut :

Ho : Tidak ada pengaruh yang signifikan antara variabel independen terhadap variabel dependen. Ha : Ada pengaruh yang signifikan antara variabel independen terhadap variabel dependen.

\section{Uji -t}

$\mathrm{Uji}$ - $\mathrm{t}$ ini digunakan untuk membuktikan adanya pengaruh yang signifikan antara kualitas pelayanan yang dilihat bukti fisik, keandalan, daya
Tanggap, jaminan dan empati yang diberikan oleh PT. PLN Rayon Malili terhadap kepuasan pelanggan secara parsial. Ketentuan $\mathrm{t}$ tabel (Nurgiyantoro, dkk, 2004:192) : $\alpha=0,05$ (satu sisi) $; \mathrm{n}-1=100-1=99$, maka t tabel $=1,660$.

Ketentuan penerimaan hipotesis yaitu :

Ha ditolak bila sig. $>0,05$ atau $\mathrm{t}$ hitung $<\mathrm{t}$ tabel Ha diterima bila sig. $\leq 0,05$ atau $\mathrm{t}$ hitung $>\mathrm{t}$ tabel Berdasarkan hasil pengolahan dengan program SPSS 20.0 for windows maka di dapat hasil uji - t, yang hasilnya dirangkum pada tabel berikut ini:

Tabel 7: Hasil Uji t

\begin{tabular}{|l|c|c|c|}
\hline \multicolumn{1}{|c|}{ Variabel } & Hasil Uj i- $\mathrm{t}$ & $\mathrm{t}$ tabel &, 000 \\
\hline Status sosial ekonomi & 9,438 & 1,660 &, 176 \\
\hline Pendidikan & $-1,364$ & 1,660 &, 000 \\
\hline Sertifikat tanah & 4,243 & 1,660 &, \\
\hline
\end{tabular}

Sumber : data diolah 2013

Hasil uji - t dari status sosial ekonomi, pendidikan dan kesadaran kepemilikan sertifikat tanah diperoleh nilai sig. lebih kecil $(<)$ dari 0,05 dan $\mathrm{t}$ hitung $>\mathrm{t}$ tabel,sehingga hipotesis yang menyatakan bahwa status sosial ekonomi, pendidikan berpengaruh signifikan terhadap sertifikat tanah secara parsial diterima.

\section{Uji $-\mathbf{F}$}

Uji - F ini digunakan untuk membuktikan adanya pengaruh yang signifikan antara status sosial ekonomi dan pendidikan terhadap kesadaran kepemilikan sertifikat tanah secara simultan.

Ketentuan F tabel : (Usman dan Akbar, $\mathrm{df} 1=\mathrm{m}=2$

df $2=n-m-1=100-2-1=97$

Keterangan :

$\mathrm{n}=$ sampel

$\mathrm{m}=$ variabel bebas

maka $\mathrm{F}$ tabel $=3,090$

Ketentuan penerimaan hipotesis yaitu

Ha ditolak bila sig. $>0,05$ atau $\mathrm{F}$ hitung $<\mathrm{F}$ tabel Ha diterima bila sig. $\leq 0,05$ atau $\mathrm{F}$ hitung $>\mathrm{F}$ tabel

Berdasarkan hasil pengolahan dengan program SPSS 20.0 for windows maka di dapat hasil uji $-\mathrm{F}$, yang hasilnya dapat dilihat sebagai berikut:

dkk, 2006:245), 
Tabel 8: Hasil Uji F

\begin{tabular}{|c|c|c|}
\hline Variabel & Uji-f & f-tabel \\
\hline $\begin{array}{c}\text { Status sosial } \\
\text { ekonomi }\end{array}$ & 66,804 & 3,090 \\
\cline { 1 - 1 } Pendidikan & & \\
\cline { 1 - 2 } $\begin{array}{c}\text { Kepemilikan } \\
\text { sertifikat tanah }\end{array}$ & & \\
\hline
\end{tabular}

Hasil uji - F sebesar 66,804 dengan sig. 0,000. Nilai sig. Diperoleh nilai lebih kecil $(<)$ dari 0,05 dan $\mathrm{F}$ hitung $>\mathrm{F}$ tabel, sehingga membuktikan hipotesis yang menyatakan bahwa

Tabel 9: Koefisien Determinasi

\section{Model Summary}

\begin{tabular}{|l|c|c|c|c|}
\hline Model & $\mathrm{R}$ & $\mathrm{R}$ Square & Adjusted.R Square & Std. Error of the Estimate \\
\hline 1 & 0,762 &, 579 &, 571 & 1,406 \\
\hline
\end{tabular}

Nilai adjusted $r$ square sebesar 0,571, yang artinya status sosial ekonomi dan pendidikan mampu menjelaskan kesadaran kepemilikian sertifikat tanah sebesar $57,1 \%$, sementara sisanya sebesar $\quad 42,9 \% \quad(100 \%-57,1 \%) \quad$ kesadaran kepemilikan sertifikat tanah di pengaruh faktor lain.

\section{Pembahasan}

Di bagian ini akan dipaparkan hak-hak atas tanah yang terdiri dari hak milik, hak guna usaha, hak guna bangunan, dan hak pakai.

Hak milik merupakan hakterkuat atas suatu tanah, dalam arti hak ini bersifat mutlak dan tidak dapat diganggu-gugat oleh pihak lainnya. Definisi berdasarkan pasal 20 ayat (1) UUPA. "hak milik adalah hak turun-temurun, terkuat, dan terpenuhi status sosial ekonomi dan pendidikan berpengaruh signifikan terhadap kesadaran kepemilikian secara bersama-sama diterima.

\section{Koefisien Determinasi}

Koefisien determinasi digunakan untuk mengetahui kemampuan variabel independen dalam menjelaskan variabel dependen. Besarnya koefesien determinasi dapat dilihat pada adjsuted $r$ square dan dinyatakan dalam presentase. Hasil koefisien determinasi antara status sosial ekonomi dapat dilihat pada tabel berikut ini.dan pendidikan terhadap kesadaran kepemilikan sertifikat tanah di Kabupaten Luwu Timur. yang dapat dipunyai orang atas tanah, dengan mengingat ketentuan dalam pasal 6."

Pemberian sifat terkuat dan terpenuhi, tidak berarti bahwa hak itu merupakan hak yang mutlak, tak terbatas, dan tidak dapat diganggugugat sebagai hak menurut pengertiannya yang asli dulu. Hak milik mempunyai fungsi sosial sebagaimana disebutkan dalam pasal 6 UUPA.

Kata-kata "terkuat dan terpenuhi" itu dimaksud untuk membedakannya dengan hak guna usaha, hak guna bangunan, hak pakai, dan lainlain, yaitu untuk menunjukkan bahwa diantara hak-hak atas tanah yang dapat dimiliki orang, hak miliklah yang mempunyai kekuatan hukum paling kuat dan paling penuh.

Sebagai suatu hak, hak milik tentunya memiliki fungsi yang lain, yakni fungsi ekonomi. Fungsi ekonomi dari hak milik dapat dilihat dari 
diperbolehkannya hak milik dijadikan sebagai jaminan utang dengan dibebani hak tanggungan sebagaimana diatur dalam pasal 25 UUPA, "hak milik dapat dijadikan jaminan utang dengan dibebeni hak tanggungan.

Dengan diperbolehkannya hak milik atas suatu masalah untuk dijadikan jaminan utang, semakin memperjelas bahwa tanah sebagai benda tidak bergerak memiliki nilai ekonomi sehimgga sudah sepantasnya jika ada pembatasanpembatasan terdapat kepemilikan atas tanah.

Pembatasan-pembatasan tersebut diatur dalam pasal 21 ayat (1) dan ayat (2) UUPA yang menentukan bahwa yang berhak atas hak milik adalah:

- Warga negara indonesia;

- Badan-badan hukum yang ditetapkan oleh pemerintah dan memenuhi syarat-syarat dapat mempunyai hak milil.

Sementara itu, orang-orang wajib melepaskan hak milik atas

Tanah menurut pasal 21 ayat (3) dan ayat (4) UUPA sebagain berikut.

$\checkmark$ Warga negara asing yang sudah berlakunya UUPA memperolah hak milik, karena pewarisan tanpa wasiat atau percampuran harta karena perkawianan.

$\checkmark$ Warga Negara Indonesia yang mempunyai hak milik dan setelah berlakunya UUPA ini kehilangan kewarganegaraannya.

$\checkmark$ Seseorang yang di samping kewarganegaraan Indonesianya mempunyai kewarganegaraan asing.

Ketentuan atas pasal ini merupakan pelaksanaan dari pemutihan atas hak milik dari warga negara Belanda dan Timur Asing yang berdiam di Indonesia sejak masah penjajahan pada saat itu, segala hal yang berkaitan dengan pertahanan tunduk kepada hukum yang diberlakukan oleh pemerintah Hindia Belanda di Indonesia, serta pada masa itu diberlakukan pembagian golongan penduduk menjadi golongan Eropa, Timur Asing, dan Pribumi.

Orang-orang yang disebutkan dalam pasal 21 ayat (3) dan ayat (4) UUPA tersebut wajib melepaskan hak miliknya dalam jangka waktu satu tahun sejak diperolehnya hak tersebut atau hilangnya kewarganegaraan itu. Dengan demikian, hak tersebut hapus karena hukum dan tanahnya jatuh pada negara, dengan ketentuan bahwa hak-hak pihak lain yang membebaninya tetap berlangsung.

\section{Kesimpulan}

Berdasarkan pada penjelasan sebelumnya maka dapat disimpulkan bahwa:

Interpretasi dari regresi di atas adalah sebagai berikut :

1. Konstanta (a)

Ini berarti semua variabel bebas memiliki nilai nol (0) maka nilai variabel terikat sebesar 3,503

2. Status sosial ekonomi $\left(\mathrm{X}_{1}\right)$ terhadap beta $(\mathrm{Y})$

Nilai koefisien status sosial ekonomi untuk variabel $\mathrm{X}_{1}$ sebesar 0,833 . Hal ini mengandung arti bahwa setiap kenaikan bukti fisik satu satuan maka variabel beta (Y) akan naik sebesar 0,833 dengan asumsi bahwa variabel bebas yang lain dari model regresi adalah tetap.

3. pendidikan $\left(\mathrm{X}_{2}\right)$ terhadap beta $(\mathrm{Y})$ 
Nilai koefisien pendidikan untuk variabel $\mathrm{X}_{2}$ sebesar -0,111. Hal ini mengandung arti bahwa setiap kenaikan keandalan satu satuan maka variabel beta (Y) akan turun sebesar 0,111 dengan asumsi bahwa variabel bebas yang lain dari model regresi adalah tetap

\section{Saran}

1. Untuk meningkatkan pengetahuan masyarakat harusnya pengetahuan masyarakat bisa ditingkatkan dengan melalui penyuluhan.

2. Untuk mendapatkan peningkatan status sosial maka diharapkan bisa meningkatkan kesadaran kepemilikan sertifikat tanah.

\section{Daftar Pustaka}

Sembiring, Jimmy. 2002. Panduan Sertifikat Tanah. Jakarta : Visi

Media Indonesia, "Undang-undang No. 5 Tahun 1960 Tentang Peraturan

Dasar Pokok-Pokok Agraria”, Jakarta, 1960.

Indonesia, "Peraturan Pemerintah Republik Indonesia Nomor 24

Tahun 1997 Tentang Pendaftaran Tanah”, Jakarta, 1997.

Indonesia, $\mathrm{M}$ enteri Negara Agraria/Kepala Badan Pertanahan Nasional,"Peraturan Menteri Negara Agraria/Kepala Badan Pertanahan Nasional Nomor 9 Tahun 1999 tentang Tata Cara Pemberian dan Pembatalan Hak atas Tanah Negara dan Hak Pengelolaan, Jakarta, 1999. 